\title{
Dephosphorization of Molten Pig Iron Containing Chromium by Lithium Carbonate*
}

\author{
By Takashi YAMAUCHI** and Shigeaki MARUHASHI**
}

\begin{abstract}
Synopsis
The dephosphorization of molten pig iron containing $18 \%$ chromium by the addition of $\mathrm{Li}_{2} \mathrm{CO}_{3}$ has been studied using a laboratory scale high frequency induction furnace. The degrees of dephosphorization, desulfurization, and denitrification obtained by adding $60 \sim 125 \mathrm{~g} / \mathrm{kg}$-metal of $\mathrm{Li}_{2} \mathrm{CO}_{3}$ to molten pig iron $(0.03 \% \mathrm{P}, 0.03 \% \mathrm{~S}, 0.02 \% \mathrm{~N})$ containing chromium in a graphite crucible were more than $80 \%$. The oxidation loss of chromium was less than $0.5 \%$. The degree of dephosphorization by the addition of $\mathrm{Li}_{2} \mathrm{CO}_{3}$ was 2.1 times as large as that by the addition of $\mathrm{Na}_{2} \mathrm{CO}_{3}$ when the same weight of fux was added to the melt. The slag basicity after treatment by $\mathrm{Li}_{2} \mathrm{CO}_{3}$ was higher than that by $\mathrm{Na}_{2} \mathrm{CO}_{3}$. The degree of dephosphorization decreased remarkably with increasing temperature. It is preferable to treat the pig iron at a temperature below $1480^{\circ} \mathrm{C}$. The carbon content of pig iron had a remarkable effect on the dephosphorization reaction. When the carbon content was low $(3.5 \%)$, the oxidation loss of chromium was very large and the degree of dephosphorization was lowered to about $20 \%$. By $X$-ray diffraction analysis, $\mathrm{Li}_{4} \mathrm{SiO}_{4}$ and $\mathrm{LiCrO}_{2}$ were identified in the slag after treatment, and $\mathrm{Li}_{3} \mathrm{PO}_{4}$ in the phosphorus-enriched slag.
\end{abstract}

\section{Introduction}

It has been reported ${ }^{1-5)}$ that phosphorus enhances the susceptibility to stress-corrosion cracking in austenitic stainless steels and that to hot cracking in austenitic single-phase stainless steels. However, industrial dephosphorization processes are still being developed. Many laboratory scale experiments have been made on the dephosphorization of molten steel or iron containing chromium by adding such fluxes as $\mathrm{Na}_{2} \mathrm{CO}_{3},{ }^{1)} \mathrm{Ca}-\mathrm{CaF}_{2},{ }^{7-9)} \mathrm{CaC}_{2}-\mathrm{CaF}_{2}{ }^{10-12)} \mathrm{CaO}-$ $\mathrm{FeCl}_{2}$, ${ }^{13)} \mathrm{CaC}_{2},{ }^{14)}$ or $\mathrm{Ca} .{ }^{15}$ ) These studies can generally be classified into the following two; reducing dephosphorization and oxidizing dephosphorization methods. In the case of reducing dephosphorization method, it is necessary to complete the dephosphorization reaction in reducing or neutral atmosphere without oxidizing calcium in slag as a dephosphorizing agent. Furthermore if the slag after dephosphorization treatment is allowed to stand, phosphine, $\mathrm{PH}_{3}$, is formed by the following reaction (Eq. (1)).

$$
\begin{aligned}
& \mathrm{Ca}_{3} \mathrm{P}_{2} \text { (in slag) }+3 \mathrm{H}_{2} \mathrm{O} \\
& \quad \longrightarrow 3 \mathrm{CaO} \text { (in slag) }+2 \mathrm{PH}_{3}
\end{aligned}
$$

Therefore it has been said ${ }^{12)}$ that the slag must be treated so as not to generate such a poison gas. On the other hand, the oxidizing dephosphorization method is free from such a problem and can be performed in the air, that is, it has the practical ease. However, from a study ${ }^{6}$ ) on the oxidizing dephosphorization of molten steel containing chromium by the addition of alkaline metal compounds $\left(\mathrm{Na}_{2} \mathrm{CO}_{3}\right.$ flux and $\mathrm{K}_{2} \mathrm{CO}_{3}$ flux), it has been found the fact that the oxidation of chromium occurred predominantly, but not dephosphorization.

From the preliminary experiments, it has also been found that among alkaline metal compounds, $\mathrm{Li}_{2} \mathrm{CO}_{3}$ shows a marked effect on the refining of molten pig iron containing chromium. This paper concerns a subsequent fundamental research on the dephosphorization of molten pig iron containing chromium.

\section{Experimentals}

A schematic diagram of the furnace used and the experimental conditions adopted are shown in Fig. 1 and Table 1, respectively. Chromium pig iron saturated with carbon of $1.2 \mathrm{~kg}$ in weight was melted in a graphite crucible with a high frequency induction furnace. The carbon content of pig iron containing $17.0 \%$ chromium was $6.1 \%$ at $1430{ }^{\circ} \mathrm{C}$. In the molten bath, powdered $\mathrm{Li}_{2} \mathrm{CO}_{3}$ was added by $10 \sim 125 \mathrm{~g} / \mathrm{kg}$-metal as a dephosphorizing flux. Several parts of flux were added every 3 to $5 \mathrm{~min}$. The metal samples were taken with a silica tube by suction at intervals of 5 to 10 min during the experimental run, and the slag sample was taken with a steel spoon at the end of runs. The experimental time was $40 \mathrm{~min}$ in most cases. In the experiment to study the effect of carbon content of pig iron on the dephosphorization, magnesia crucible was used as an inner crucible. Temperature of the metal bath was controlled by measuring the temperature of the outer crucible after correcting the difference in temperature between inner and outer crucibles. Most of the experiments were made by keeping the metal at $1430 \pm$ $10^{\circ} \mathrm{C}$. In the case of examining the temperature dependency of the degree of dephosphorization, the metal was kept at $1430,1460,1500$ and $1600{ }^{\circ} \mathrm{C}$. Although most of the experiments were made in the air, the top blowing of $\mathrm{CO}_{2}$ gas was additionally applied to some experiments. Change in the composition of slag with time was examined by adding the total amount of flux at once in the beginning to molten pig iron of $3 \mathrm{~kg}$ in weight. In this case, the slag samples were taken at intervals of 5 to $10 \mathrm{~min}$ during the run. As a flux, $\mathrm{Na}_{2} \mathrm{CO}_{3}$ was also used in order to compare the result obtained with that of $\mathrm{Li}_{2} \mathrm{CO}_{3}$ addition.

Since the slag was in the activated state, samples were ground in ethyl alcohol and then dried. Con-

* Presented to the 100th ISIJ Meeting, October 1980, S893, at Kyushu University in Fukuoka. Manuscript received December 17, 1982. (C) 1983 ISIJ

** Shunan R \& D Laboratory, Nisshin Steel Co., Ltd., Tonda, Shin-nanyo 746. 


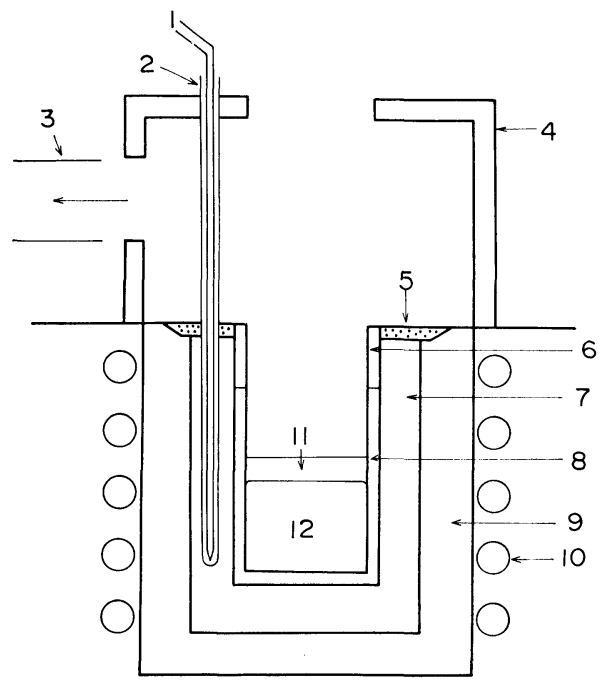

1. Thermocouple

7. Graphite outer crucible

2. Alumina tube

8. Graphite inner crucible

3. Exhaust pipe

9. Magnesia stamp

4. Hood

10. Induction coil

5. Graphite powder

11. Molten slag

6. Graphite pipe

12. Molten metal

Fig. 1. A schematic diagram of furnace used.

Table 1. Experimental conditions.

\begin{tabular}{|c|c|c|c|c|c|}
\hline Furnace & \multicolumn{5}{|c|}{ High frequency induction furnace } \\
\hline Grucible & \multicolumn{5}{|c|}{ Graphite* or Magnesia } \\
\hline Weight of metal & \multicolumn{5}{|c|}{$1.2 \mathrm{~kg} *$ or $3.0 \mathrm{~kg}$} \\
\hline \multirow{2}{*}{$\begin{array}{l}\text { Initial composi- } \\
\text { tion of metal } \\
\text { (\%) }\end{array}$} & C & $\mathrm{Si}$ & $\mathbf{S}$ & $\mathrm{Cr}$ & $\mathrm{N}$ \\
\hline & $\begin{array}{l}2,3.5 \\
\text { or } 6^{*}\end{array}$ & $\begin{array}{ll}\operatorname{tr} . & \sim \\
1.2 & 0.03\end{array}$ & 0.03 & 18 & 0.02 \\
\hline Flux & \multicolumn{5}{|c|}{$\begin{array}{l}\mathrm{Li}_{2} \mathrm{CO}_{3} * \text { or } \mathrm{Na}_{2} \mathrm{CO}_{3} \text { (Chemical } \\
\text { reagent, 1st grade) }\end{array}$} \\
\hline $\begin{array}{l}\text { Amount of flux } \\
\text { added }\end{array}$ & \multicolumn{5}{|c|}{$10 \sim 125 \mathrm{~g} / \mathrm{kg}$-metal } \\
\hline $\begin{array}{l}\text { Temperature of } \\
\text { metal }\end{array}$ & \multicolumn{5}{|c|}{$1430^{\circ} \mathrm{C}^{*}, 1400 \sim 1600^{\circ} \mathrm{G}$} \\
\hline Atmosphere & \multicolumn{5}{|c|}{$\begin{array}{l}\text { In the air (without* or with the } \\
\text { top blowing of } \mathrm{CO}_{2} \text { gas) }\end{array}$} \\
\hline
\end{tabular}

* Mainly used

tents of total lithium (T.Li) and $\mathrm{Li}_{2} \mathrm{CO}_{3}$ in slag were obtained by the atomic absorption method and by determining the amount of $\mathrm{CO}_{2}$ gas using a Schrötter meter, respectively. Phosphorus content of pig iron containing chromium was determined by the molybdenum blue method.

\section{Results}

\section{Rifining Characteristics of $\mathrm{Li}_{2} \mathrm{CO}_{3}$}

As shown in Fig. 2, phosphorus, sulfur and nitrogen in molten pig iron containing chromium were removed remarkably by the addition of $\mathrm{Li}_{2} \mathrm{CO}_{3}$. On the other hand, the oxidation loss of chromium was usually less than $0.5 \%$. As shown in Fig. 3, silicon was predominantly oxidized in the range above $0.5 \% \mathrm{Si}$,

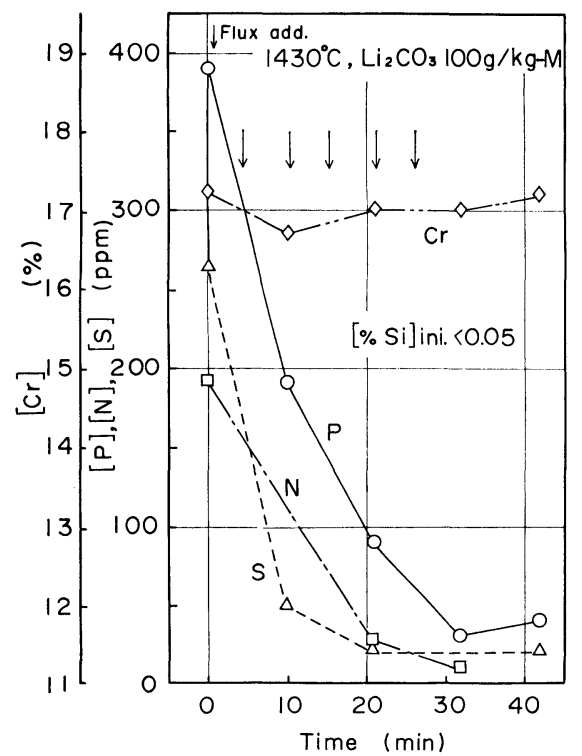

Fig. 2. Typical example of the change in composition of molten pig iron containing chromium after the addition of $\mathrm{Li}_{2} \mathrm{CO}_{3}$.

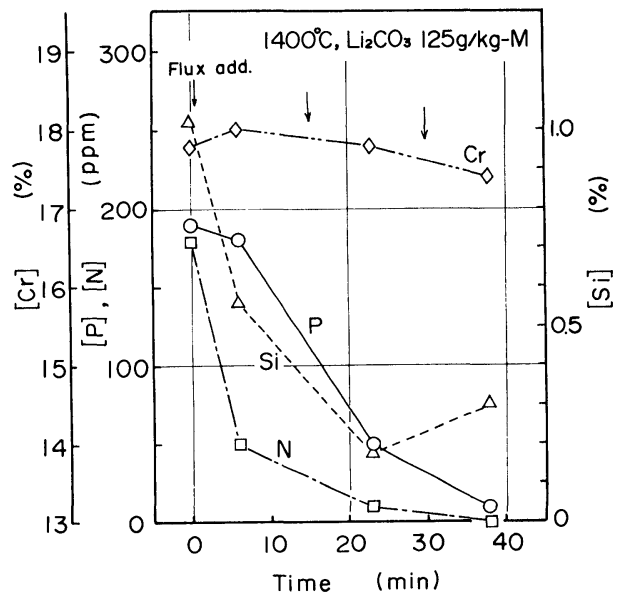

Fig. 3. Typical example of the change in composition of molten pig iron containing chromium after the addition of $\mathrm{Li}_{2} \mathrm{CO}_{3}$.

but silicon and phosphorus were simultaneously oxidized in the range below that. When the amount of $\mathrm{Li}_{2} \mathrm{CO}_{3}$ added was larger than $100 \mathrm{~g} / \mathrm{kg}$-metal, the degree of dephosphorization $\left(D_{p}\right)$ for pig iron of high silicon content (about $1 \% \mathrm{Si}$ ) was not smaller than that for pig iron of low silicon content. But, when the amount of $\mathrm{Li}_{2} \mathrm{CO}_{3}$ added was smaller than $60 \mathrm{~g} / \mathrm{kg}$-metal, $D_{p}$ decreased with increasing content of silicon in pig iron. In this case, $D_{p}$ was considered to be effected by the basicity of slag formed as mentioned later. The content of carbon in pig iron $([\% \mathrm{G}])$ was kept at a constant value during the run because a graphite crucible was used. The effect of the added amount of $\mathrm{Li}_{2} \mathrm{CO}_{3}$ on $D_{p}$ was remarkable when the added amount was in the range of $10 \sim$ $100 \mathrm{~g} / \mathrm{kg}$-metal, as shown in Fig. 4. In the runs $D$, $E$ and $F$ in the same figure, $\mathrm{CO}_{2}$ gas, $\mathrm{Na}_{2} \mathrm{CO}_{3}$ and $\mathrm{FeO}$ were added besides the addition of $\mathrm{Li}_{2} \mathrm{CO}_{3}$ to compensate the shortage of oxidizing source. The value of $D_{p}$ reached about $90 \%$ when $\mathrm{Li}_{2} \mathrm{CO}_{3}$ of 


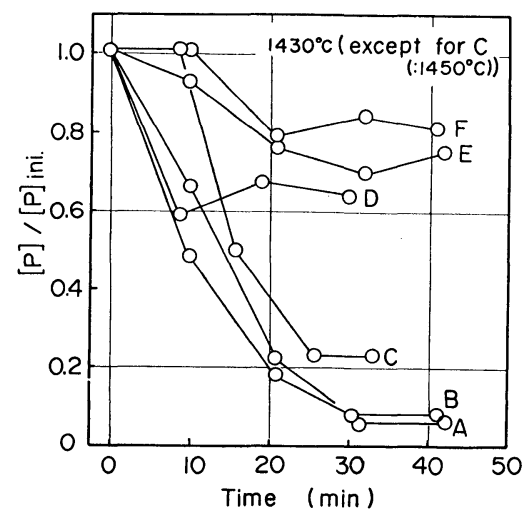

Amount of flux (g/kg-metal)

and the top blown gas: $[\% \mathrm{Si}]_{\text {ini. }}$.

$\begin{array}{llll}\text { A: } & \mathrm{Li}_{2} \mathrm{CO}_{3} & 100: & 0.05 \\ \text { B: } & \mathrm{Li}_{2} \mathrm{CO}_{3} & 100: & 0.05 \\ \text { C: } & \mathrm{Li}_{2} \mathrm{CO}_{3} & 62.4: & 0.55\end{array}$

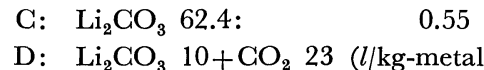

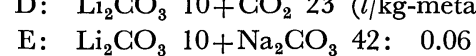

$\mathrm{F}: \mathrm{Li}_{2} \mathrm{CO}_{3} 10+\mathrm{FeO} 42: \quad 0.05$

Fig. 4. Effect of the amount of flux added on the degree of dephosphorization.

$100 \mathrm{~g} / \mathrm{kg}$-metal was added and about $80 \%$ for the addition of $60 \mathrm{~g} / \mathrm{kg}$-metal. In the latter case, the initial content of silicon was $0.55 \%$. However, when the flux of $10 \mathrm{~g} / \mathrm{kg}$-metal was added, $D_{p}$ remained 20 to $40 \%$ in spite of supplying any oxidizing agent.

The dephosphorizing power of $\mathrm{Li}_{2} \mathrm{CO}_{3}$ was compared with that of $\mathrm{Na}_{2} \mathrm{CO}_{3}$ and is shown in Fig. 5. The value of $D_{p}$ by the addition of $\mathrm{Li}_{2} \mathrm{CO}_{3}$ was 2.1 times as large as that by adding $\mathrm{Na}_{2} \mathrm{CO}_{3}$ when the same weight of flux was added, and was 1.5 times as large as that by the addition of $\mathrm{Na}_{2} \mathrm{CO}_{3}$ when the molar number of flux added was the same.

\section{Change in Slag Composition during Dephosphorization Treatment}

Figure 6 shows the change in slag composition with time after adding $\mathrm{Li}_{2} \mathrm{CO}_{3}$ in one portion. A rapid decrease in the content of $\mathrm{Li}_{2} \mathrm{CO}_{3}$ in slag $\left(\left(\% \mathrm{Li}_{2} \mathrm{CO}_{3}\right)\right)$ and rapid increases in $\left(\% \mathrm{Li}_{2} \mathrm{O}\right),\left(\% \mathrm{Cr}_{2} \mathrm{O}_{3}\right),\left(\% \mathrm{SiO}_{2}\right)$ and $(\% \mathrm{P})$ were observed just after the addition of $\mathrm{Li}_{2} \mathrm{CO}_{3}$. Subsequently, slow decreases in the content of iron oxides formed (expressed as the total iron content (T.Fe) $)$ and in $\left(\% \mathrm{Li}_{2} \mathrm{O}\right)$ and slow increases in $\left(\% \mathrm{SiO}_{2}\right),\left(\% \mathrm{Cr}_{2} \mathrm{O}_{3}\right)$ and $(\% \mathrm{P})$ occurred, but $\left(\% \mathrm{Li}_{2} \mathrm{CO}_{3}\right)$ did not show any change. Accordingly the oxidizing source was considered to be $\mathrm{CO}_{2}$ gas generated by the decomposition of $\mathrm{Li}_{2} \mathrm{CO}_{3}$ and iron oxides formed just after the addition of flux. A rapid increase in $\left(\% \mathrm{Cr}_{2} \mathrm{O}_{3}\right)$ at the last stage of the run found in Fig. 6 is not considered to be normal behavior, but the reason is not clarified yet. Figure 7 shows the change in slag composition with time in the case that the initial content of silicon is high $\left([\% \mathrm{Si}]_{\mathrm{ini} .}=1.14\right)$. In this case the dephosphorization did not occur because of low slag basicity. And, the content of $\mathrm{SiO}_{2}$ was high, but the formation of chromium oxide was found to be suppressed as compared with the data of Fig. 6 . In contrast with this, the con-

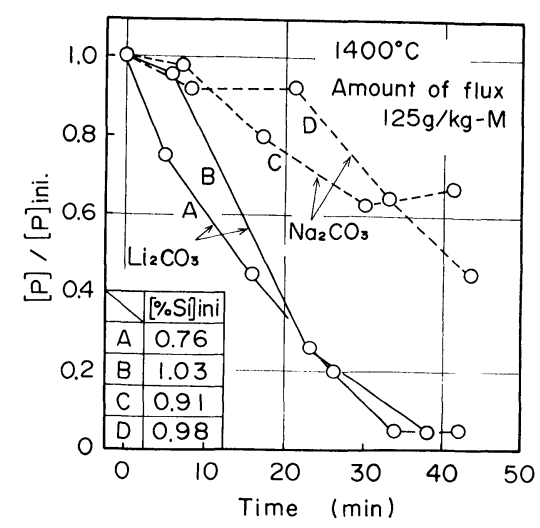

Fig. 5. Comparison of the dephosphorizing powers obtained by the addition of $\mathrm{Li}_{2} \mathrm{CO}_{3}$ and $\mathrm{Na}_{2} \mathrm{CO}_{3}$.

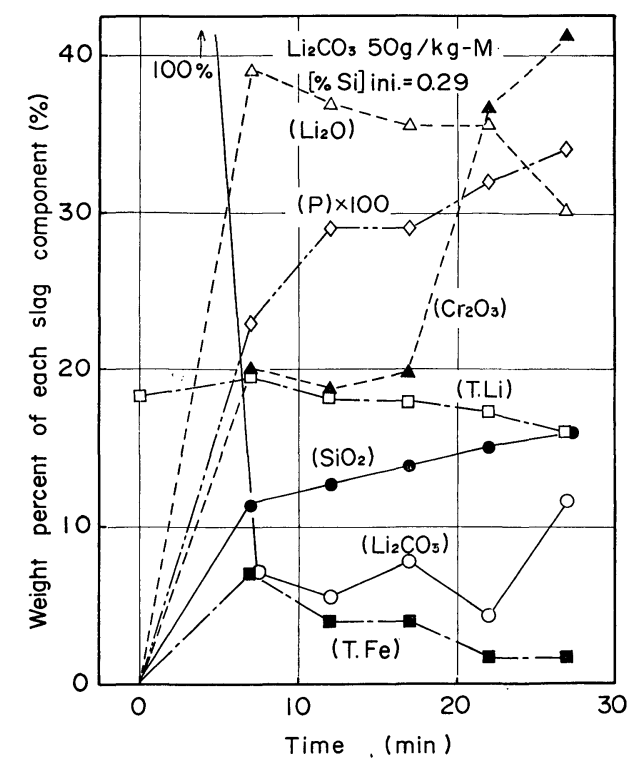

Fig. 6. Typical example of the change in composition of slag during treatment.

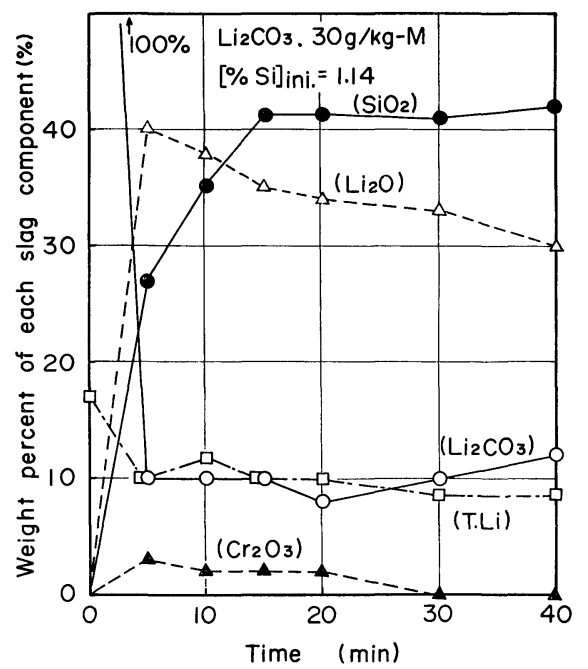

Fig. 7. Typical example of the change in composition of slag during treatment.

tent of chromium oxide becomes high in the case of low initial content of silicon, and consequently the slag tended to lose the fluidity without the intermittent addition of $\mathrm{Li}_{2} \mathrm{CO}_{3}$. 
Typical composition of slag obtained after dephosphorization treatment is shown in Table 2. The phosphorus distribution ratio $\left(L_{p} \equiv(\mathrm{P}) /[\mathrm{P}]\right)$ reached up to the value of 400 to 700 . Not only in the case that $[\% \mathrm{Si}]_{\text {ini. }}$ was low, but that the amount of $\mathrm{Li}_{2} \mathrm{CO}_{3}$ added was small, the tendency of increasing content of chromium oxide was observed. The latter was supposed to be resulted from the phenomenon that the metal surface did not perfectly covered with slag. The added $\mathrm{Li}_{2} \mathrm{CO}_{3}$ remained by 5 to $12 \%$ in slag.

\section{Temperature Dependence of Dephosphorization Reaction}

As shown in Fig. 8, the degree of dephosphorization showed a remarkable temperature dependence on the dephosphorization treatment by $\mathrm{Li}_{2} \mathrm{CO}_{3}$, that is, $D_{p}$ decreased rapidly with increasing temperature. It was below $1480^{\circ} \mathrm{C}$ wherein a large degree of dephosphorization could be obtained. The range of temperature suitable for the dephosphorization treatment was considerably narrow, since in the case of $18 \%$ chromium pig iron saturated with carbon the surface of metal bath began to solidify at some $1380^{\circ} \mathrm{C}$.

\section{Effect of $[\% \mathrm{C}]$ on Dephosphorization Reaction}

The effects of $[\% \mathrm{C}]$ on $D_{p}$ and on the oxidation loss of chromium are shown in Fig. 9. When [\% $\mathrm{C}]$ was about 3.5, the oxidation of chromium was vigorous and the slag lost the fluidity soon after the addition of $\mathrm{Li}_{2} \mathrm{CO}_{3}$. In the case that [\% $\%$ ] was about 2 , the dephosphorization did not occur at all but the loss of chromium became still larger. As shown in Table 2 , the content of chromium oxide is remarkably high when $[\% \mathrm{C}]$ is equal to 3.54 as compared with the values in the cases of the saturated carbon content and of adding $\mathrm{Li}_{2} \mathrm{CO}_{3}$ of nearly the same amount. Low value of $\left\{\left(\% \mathrm{Li}_{2} \mathrm{CO}_{3}\right)+\left(\% \mathrm{Li}_{2} \mathrm{O}\right)\right\}$ may be resulted from an increase in the slag volume due to the vigorous oxidation of chromium. Large ratio of $\left(\% \mathrm{Li}_{2} \mathrm{CO}_{3}\right) /$ $\left(\% \mathrm{Li}_{2} \mathrm{O}\right)$ may suggest that the decomposition of $\mathrm{Li}_{2} \mathrm{CO}_{3}$ did not sufficiently proceed. The experiments for the metals unsaturated with carbon and saturated with carbon were made by using magnesia and graphite crucibles, respectively. Therefore the difference in the results of the two is considered to be caused not only by the difference in $[\% \mathrm{C}]$ but by the difference in crucible materials. That is, the walls of graphite crucible may reduce the slag (es- pecially, iron and chromium oxides) and supply the heat to the slag.

\section{X-ray Analysis of Slags after Treatment}

By the X-ray diffraction analysis of the slag after dephosphorization treatment, $\mathrm{Li}_{4} \mathrm{SiO}_{4}$ and $\mathrm{Li}_{2} \mathrm{O}$ were identified as strong peaks, and $\mathrm{Li}_{2} \mathrm{OH} \cdot \mathrm{H}_{2} \mathrm{O}, \mathrm{LiCrO}_{2}$ and $\mathrm{Li}_{2} \mathrm{CO}_{3}$ were identified as weak peaks as shown in Fig. 10. However, any compound containing phosphorus was not found. $\mathrm{LiOH} \cdot \mathrm{H}_{2} \mathrm{O}$ seemed to be formed by moistening of $\mathrm{Li}_{2} \mathrm{O}$ during the preparation of slag sample. On the other hand, a strong peak of $\mathrm{Li}_{3} \mathrm{PO}_{4}$ and weak peaks of $\mathrm{LiOH} \cdot \mathrm{H}_{2} \mathrm{O}, \mathrm{Li}_{2} \mathrm{O}$ and $\mathrm{Li}_{2} \mathrm{CO}_{3}$ were observed for the slag cooled after keeping $150 \mathrm{~g}$ of $\mathrm{Li}_{2} \mathrm{CO}_{3}$ and $100 \mathrm{~g}$ of $\mathrm{Fe}-25 \% \mathrm{P}$ alloy in a graphite crucible for $16 \mathrm{~min}$ at $1400^{\circ} \mathrm{C}$, as shown in Fig. 11. The formation reactions of these compounds which are identified by the X-ray analysis may be expressed as follows:

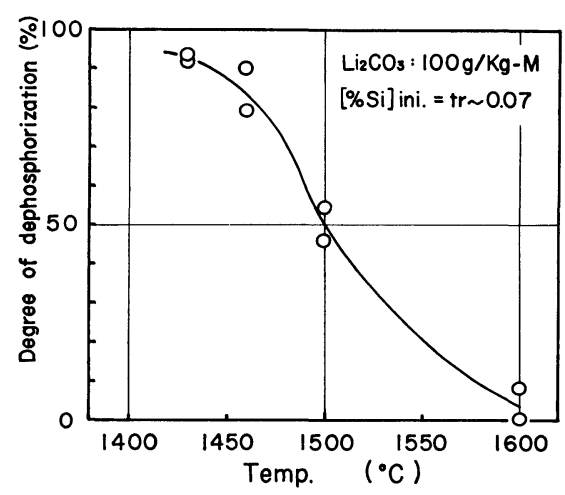

Fig. 8. Temperature dependence of $D_{p}$.

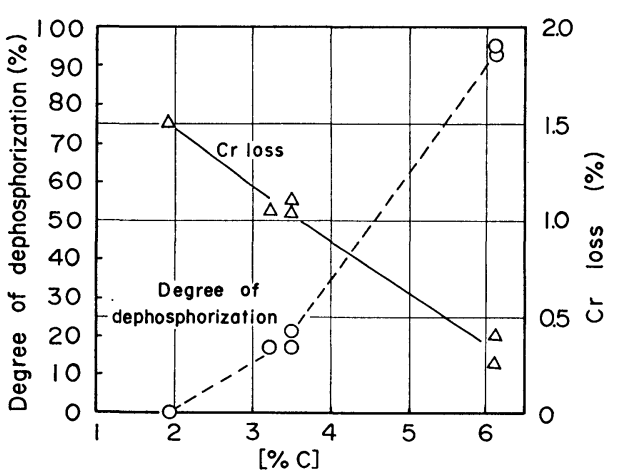

Fig. 9. Effect of $[\% \mathrm{C}]$ on $D_{p}$ and chromium loss.

Table 2. Composition of slag after treatment. $\left([\% \mathrm{C}]=\right.$ satu., $\left.1430^{\circ} \mathrm{C}\right)$

\begin{tabular}{|c|c|c|c|c|c|c|c|c|}
\hline \multirow{2}{*}[\%\mathrm{Si}]{$_{\text {ini. }}$} & \multirow{2}{*}{$\begin{array}{c}\text { Amount of } \\
\mathrm{Li}_{2} \mathrm{CO}_{3} \text { added }\end{array}$} & \multicolumn{6}{|c|}{ Composition of slag (\%) } & \multirow{2}{*}{$(\mathrm{P}) /[\mathrm{P}]$} \\
\hline & & $\left(\mathrm{Li}_{2} \mathrm{CO}_{3}\right)$ & $\left(\mathrm{Li}_{2} \mathrm{O}\right)$ & $\left(\mathrm{SiO}_{2}\right)$ & $\left(\mathrm{Cr}_{2} \mathrm{O}_{3}\right)$ & $\left(\mathrm{Fe}_{t} \mathrm{O}\right)$ & $(\mathrm{P})$ & \\
\hline 0.17 & $125 \mathrm{~g} / \mathrm{kg}$-metal & 10.49 & 45.04 & 5.63 & 21.44 & 5.61 & 0.72 & 720 \\
\hline 0.76 & $125 \mathrm{~g} / \mathrm{kg}$-metal & 10.21 & 34.35 & 29.84 & 0.64 & 1.65 & 0.22 & 72 \\
\hline 0.04 & $100 \mathrm{~g} / \mathrm{kg}$-metal & 5.74 & 58.20 & 5.26 & 8.79 & 20.56 & 1.27 & $420 *$ \\
\hline 0.10 & $10 \mathrm{~g} / \mathrm{kg}$-metal & 5.79 & 25.02 & 15.30 & 45.35 & 5.70 & 0.76 & 33 \\
\hline 0.29 & $50 \mathrm{~g} / \mathrm{kg}$-metal & 11.82 & 30.08 & 16.11 & 41.11 & 2.35 & 0.34 & 110 \\
\hline 0.07 & $100 \mathrm{~g} / \mathrm{kg}$-metal & 11.62 & 13.69 & 0.57 & 57.52 & 11.86 & 0.04 & $0.48^{* *}$ \\
\hline
\end{tabular}

* $1460{ }^{\circ} \mathrm{C}$

$* *[\% \mathrm{C}]=3.54$ 


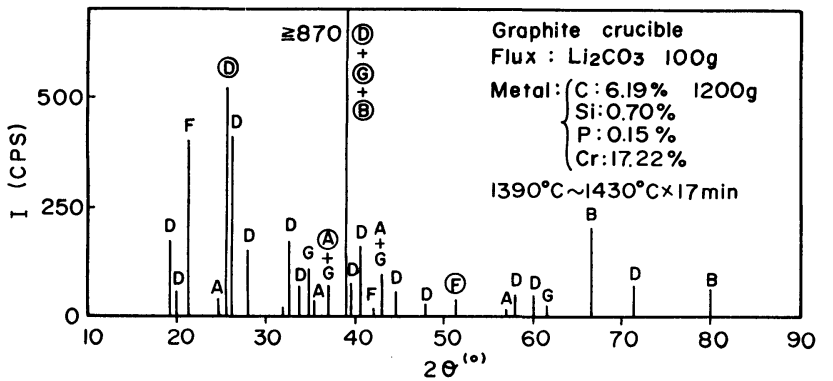

F: $\mathrm{LiCrO}_{2} \quad \mathrm{D}: \mathrm{Li}_{4} \mathrm{SiO}_{4} \quad \mathrm{G}: \quad \mathrm{LiOH} \cdot \mathrm{H}_{2} \mathrm{O}$ B: $\mathrm{Li}_{2} \mathrm{O} \quad \mathrm{A}: \mathrm{Li}_{2} \mathrm{CO}_{3}$ A circled symbol means the strongest peak of the compound.

Fig. 10. X-ray diffraction pattern of the slag after the treatment.

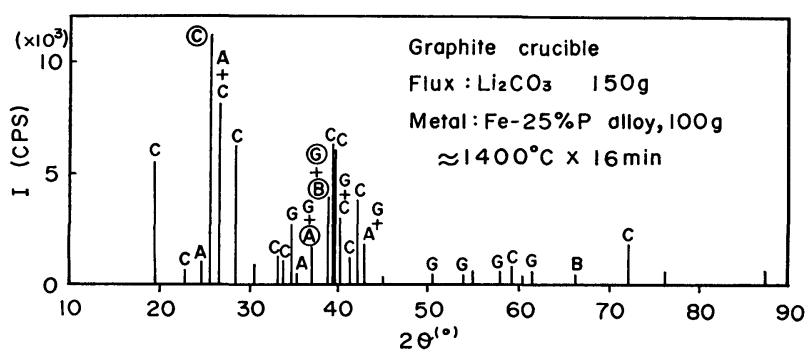

C: $\mathrm{Li}_{3} \mathrm{PO}_{4}$ (high temp.) A: $\mathrm{Li}_{2} \mathrm{CO}_{3}$ B: $\mathrm{Li}_{2} \mathrm{O}$

$\mathrm{G}: \mathrm{LiOH} \cdot \mathrm{H}_{2} \mathrm{O}$

A circled symbol means the strongest peak of the compound.

Fig. 11. X-ray diffraction pattern of the phosphorusenriched slag.

$$
\begin{aligned}
& \mathrm{Li}_{2} \mathrm{CO}_{3}(\text { slag })=\mathrm{Li}_{2} \mathrm{O}(\text { slag })+\mathrm{CO}(\mathrm{g}) \\
& +1 / 2 \mathrm{O}_{2}(\mathrm{~g}) \\
& 2 \mathrm{Li}_{2} \mathrm{O}(\text { slag })+\mathrm{SiO}_{2}(\text { slag })=\mathrm{Li}_{4} \mathrm{SiO}_{4}(\text { slag }) \ldots \\
& 1 / 2 \mathrm{Li}_{2} \mathrm{O} \text { (slag) }+1 / 2 \mathrm{Cr}_{2} \mathrm{O}_{3} \text { (slag) } \\
& =\mathrm{LiCrO}_{2} \text { (slag) } \\
& 3 / 2 \mathrm{Li}_{2} \mathrm{O} \text { (slag) }+1 / 2 \mathrm{P}_{2} \mathrm{O}_{5} \text { (slag) } \\
& =\mathrm{Li}_{3} \mathrm{PO}_{4} \text { (slag) }
\end{aligned}
$$

It is presumed from the above result that chromium oxide behaves as an acidic oxide in the slag and phosphorus is stabilized as lithium phosphate.

\section{Discussion}

\section{Relation between $L_{p}$ and Slag Composition}

The phosphorus distribution ratio increased with increasing basicity of slag as shown in Fig. 12, where the data for pig iron saturated with carbon shown in Table 2 were used again. Since $[\% \mathrm{Si}]$ after the treatment is below $0.08 \%$ in all cases, the influence of [\% $\mathrm{Si}]$ on $L_{p}$ is considered to be eliminated. Here, the basicity of slag was defined as a ratio of the molar fraction $\left(\mathcal{N}_{\mathrm{T}_{\text {.Li }} \mathrm{O}}\right)$ of $\mathrm{Li}_{2} \mathrm{O}$ stoichiometrically calculated from (\% T.Li) to the molar fraction of $\mathrm{SiO}_{2}$. Since $\left(\% \mathrm{Cr}_{2} \mathrm{O}_{3}\right)$ is considerably high in the slag formed in the current experiments, $\mathrm{Cr}_{2} \mathrm{O}_{3}$ should also be considered as a component affecting the basicity of slag.
Fig. 12.

Effect of the slag basicity on $L_{p}$.

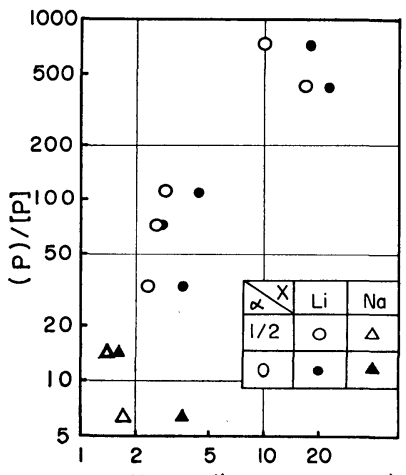

$\mathrm{NT} \cdot \mathrm{X}_{2} \mathrm{O} /\left(\mathrm{NSiO}_{2}+\alpha \cdot \mathrm{NCr}_{2} \mathrm{O}_{3}\right)$

Therefore, the basicity defined by expressing the molar fraction of acidic oxides as $\left(\mathcal{N}_{\mathrm{SiO}_{2}}+1 / 2 \mathcal{N}_{\mathrm{Cr}_{2} \mathrm{O}_{3}}\right)$ was calculated and is also shown in Fig. 12. The scatter is somewhat small as compared with that obtained by considering $\mathrm{SiO}_{2}$ as the only acidic oxide. Therefore, chromium oxide should be regarded as a component lowering the slag basicity. As for the dephosphorization treatment of pig iron containing chromium, $\left(\% \mathrm{SiO}_{2}\right)$ and $\left(\% \mathrm{Cr}_{2} \mathrm{O}_{3}\right)$ after treatment become high when the initial content of silicon is high or low. It may be difficult to keep the slag basicity high, as compared with the case of treating pig iron containing no chromium. In addition to the harmful effect mentioned above, a serious problem that the slag loses the fluidity also arises when chromium oxide in slag is high.

\section{Comparison of Dephosphorizing Powers of $\mathrm{Li}_{2} \mathrm{CO}_{3}$ and $\mathrm{Na}_{2} \mathrm{CO}_{3}$}

The phosphorus distribution ratio obtained by the similar dephosphorization treatment using $\mathrm{Na}_{2} \mathrm{CO}_{3}$ instead of $\mathrm{Li}_{2} \mathrm{CO}_{3}$ is also shown in Fig. 12 as a function of slag basicity. When $\mathrm{Na}_{2} \mathrm{CO}_{3}$ is added, the slag basicity becomes much smaller than that by the addition of $\mathrm{Li}_{2} \mathrm{CO}_{3}$. This behavior is considered to cause a small degree of dephosphorization by $\mathrm{Na}_{2} \mathrm{CO}_{3}$. In order to clarify the reason, the compositions of slags after treatment by the additions of $\mathrm{Li}_{2} \mathrm{CO}_{3}$ and $\mathrm{Na}_{2} \mathrm{CO}_{3}$ are shown in Fig. 13 for pig iron of high and low silicon contents. The characteristic of the slag by the addition of $\mathrm{Na}_{2} \mathrm{CO}_{3}$ is that $\left(\%\right.$ T. $\left.X_{2} \mathrm{O}\right)$ is low (where $X$ shows alkaline metals), and $\left(\% \mathrm{Cr}_{2} \mathrm{O}_{3}\right)$ and $\left(\% \mathrm{Fe}_{t} \mathrm{O}\right)$ are high. Since the amount of flux added is constant and $\left(\% \mathrm{SiO}_{2}\right)$ in slag after treatment corresponds the content of silicon in pig iron, the amount of slag formed is considered to be constant. In the case of $\mathrm{Na}_{2} \mathrm{CO}_{3}$ addition, it is supposed that the vaporization loss of sodium is large and chromium and iron are easily oxidized by $\mathrm{Na}_{2} \mathrm{CO}_{3}$. Equations for the decomposition of alkaline metal compounds and the equilibrium oxygen potentials for the reactions of pure substances are shown in Table 3 . From this table, it can be seen that $\mathrm{Na}_{2} \mathrm{O}$ easily decomposes into gaseous sodium. On the other hand, it is shown that $\mathrm{Li}_{2} \mathrm{O}$ is difficult to decompose into gaseous lithium, although $\mathrm{Li}_{2} \mathrm{CO}_{3}$ easily decomposes into $\mathrm{Li}_{2} \mathrm{O}$. Thermal stability of $\mathrm{Li}_{2} \mathrm{O}$ as a basic oxide seems to be superior to that of $\mathrm{Na}_{2} \mathrm{O}$. If it is assumed that 


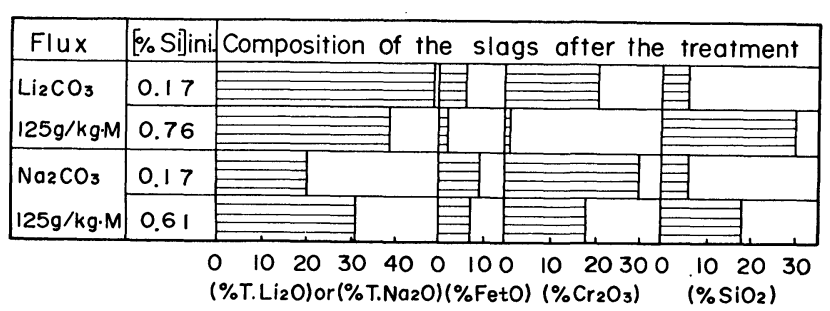

Fig. 13. Comparison of the slag compositions after the treatment.

Table 3. Equilibrium oxygen potential of reactions at $1430^{\circ} \mathrm{C}^{16)}$

\begin{tabular}{c|l}
$P_{\mathrm{O}_{2}}(\mathrm{~atm})$ & \multicolumn{1}{|c}{ Chemical equations } \\
\hline $4.9 \times 10^{-8}$ & $\mathrm{Na}_{2} \mathrm{O}(\mathrm{l})=2 \mathrm{Na}(\mathrm{g})+1 / 2 \mathrm{O}_{2}$ \\
$6.6 \times 10^{-10}$ & $\mathrm{Li}_{2} \mathrm{CO}_{3}(\mathrm{l})=\mathrm{Li} \mathrm{O}_{2}(\mathrm{~s})+\mathrm{CO}(\mathrm{g})+1 / 2 \mathrm{O}_{2}(\mathrm{~g})$ \\
$2.1 \times 10^{-11}$ & $\mathrm{Na}_{2} \mathrm{CO}_{3}(\mathrm{l})=2 \mathrm{Na}(\mathrm{g})+\mathrm{CO}(\mathrm{g})+\mathrm{O}_{2}(\mathrm{~g})$ \\
$2.5 \times 10^{-13}$ & $\mathrm{Li}_{2} \mathrm{CO}_{3}(\mathrm{l})=\mathrm{Li}_{2} \mathrm{O}(\mathrm{s})+\mathrm{C}(\mathrm{s})+\mathrm{O}_{2}(\mathrm{~g})$ \\
$9.3 \times 10^{-15}$ & $\mathrm{Na}_{2} \mathrm{CO}_{3}(\mathrm{l})=\mathrm{Na}_{2} \mathrm{O}(\mathrm{l})+\mathrm{CO}(\mathrm{g})+12 / \mathrm{O}_{2}(\mathrm{~g})$ \\
$9.5 \times 10^{-16}$ & $\mathrm{Na}_{2} \mathrm{CO}_{3}(\mathrm{l})=\mathrm{Na}_{2} \mathrm{O}(\mathrm{l})+\mathrm{C}(\mathrm{s})+\mathrm{O}_{2}(\mathrm{~g})$ \\
$2.0 \times 10^{-16}$ & $\mathrm{Li}_{2} \mathrm{CO}_{3}(\mathrm{l})=2 \mathrm{Li}(\mathrm{g})+\mathrm{CO}(\mathrm{g})+\mathrm{O}_{2}(\mathrm{~g})$ \\
$6.4 \times 10^{-23}$ & $\mathrm{Li}_{2} \mathrm{O}(\mathrm{s})=2 \mathrm{Li}(\mathrm{g})+1 / 2 \mathrm{O}_{2}(\mathrm{~g})$ \\
\hline
\end{tabular}

the activity coefficients of iron and chromium oxides in $\mathrm{Li}_{2} \mathrm{CO}_{3}$ slag are nearly equal to those in $\mathrm{Na}_{2} \mathrm{CO}_{3}$ slag, the reason why the contents of iron and chromium oxides become high in the $\mathrm{Na}_{2} \mathrm{CO}_{3}$ slag can be explained by considering the high oxygen potential supplied by flux added. Such an inference that the oxygen potential of the system was influenced by the decomposition reaction is also supported by the data shown in Table 3 in a certain extent.

Since phosphorus is removed by the oxidation in the present treatment, the value of $L_{p}$, of course, should be affected by the oxygen potential of the system. As already mentioned, $\mathrm{Na}_{2} \mathrm{CO}_{3}$ is considered to supply higher oxygen potential to the system than that by the addition of $\mathrm{Li}_{2} \mathrm{CO}_{3}$. The values of $L_{p}$ for $\mathrm{Na}_{2} \mathrm{CO}_{3}$ slag shown in Fig. 12 may be somewhat smaller if the oxygen potential of the $\mathrm{Na}_{2} \mathrm{CO}_{3}$ added system is the same to that of the $\mathrm{Li}_{2} \mathrm{CO}_{3}$ added system.

\section{Temperature Dependence of Dephosphorization Reaction}

The degree of dephosphorization obtained in the present experiments showed a remarkable temperature dependence. If it is assumed that the dephosphorization reaction at the end of experimental run is nearly in the equilibrium state, the enthalpy change of the dephosphorization reaction can be calculated from the temperature dependence of $D_{p}$. When all of phosphorus removed from metal is converted into slag, the following equation is obtained.

$$
L_{p}=\left(W_{M} / W_{S}\right) \cdot D_{p} /\left(100-D_{p}\right) .
$$

where, $W_{M}, W_{S}$ : the weights of metal and slag, respectively.

By the use of the data on the temperature dependence of $D_{p}$ shown in Fig. 8 and Eq. (6), the temperature dependence of $L_{p}$ was calculated and the result obtained is shown in Fig. 14, where $W_{S} / W_{M}$ was assumed
Fig. 14.

Temperature dependence of $L_{p}$.

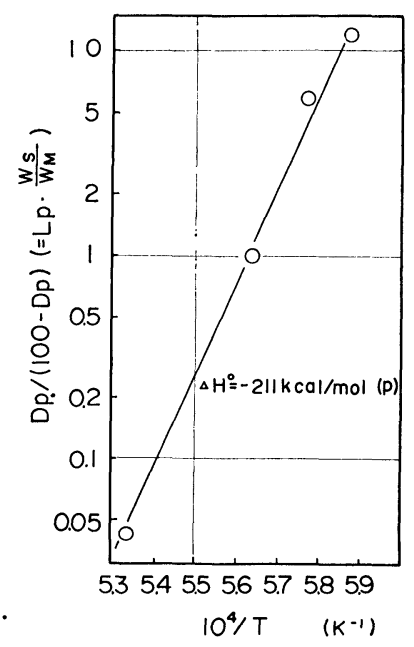

to be constant. The value of $\Delta H^{\circ}$ obtained from Fig. 14 was $-211 \mathrm{kcal} / \mathrm{mol}(\mathrm{P})$. Since no thermochemical data was reported for $\mathrm{Li}_{3} \mathrm{PO}_{4}$, the thermochemical data for $\mathrm{Na}_{3} \mathrm{PO}_{4}$ were used for the comparison of the $\Delta H^{\circ}$ value. The value of $\Delta H^{\circ}$ obtained is relatively close to the enthalpy changes of the dephosphorization reactions expressed by Eqs. (7) and (8), but not by Eq. (9).

$$
\begin{aligned}
& \underline{\mathrm{P}}+5 / 2 \underline{\mathrm{O}}+3 / 2 \mathrm{Na}_{2} \mathrm{O}(\mathrm{l})=\mathrm{Na}_{3} \mathrm{PO}_{4}(\mathrm{~s}) \\
& \Delta H^{\circ}=-236 \mathrm{kcal} / \mathrm{mol}(\mathrm{P})^{17,18)} \\
& \underline{\mathrm{P}}+5 / 2 \mathrm{FeO}(\mathrm{l})+3 / 2 \mathrm{Na}_{2} \mathrm{O}(\mathrm{l})=\mathrm{Na}_{3} \mathrm{PO}_{4}(\mathrm{~s}) \\
& +5 / 2 \mathrm{Fe}(\mathrm{l}) \\
& \Delta H^{\circ}=-164 \mathrm{kcal} / \mathrm{mol}(\mathrm{P})^{17,18)} \\
& \underline{\mathrm{P}}+5 / 2 \mathrm{Na}_{2} \mathrm{CO}_{3}(\mathrm{l})=\mathrm{Na}_{2} \mathrm{O}(\mathrm{l})+\mathrm{Na}_{3} \mathrm{PO}_{4}(\mathrm{~s}) \\
& +5 / 2 \mathrm{CO}(\mathrm{g}) \text {. } \\
& \Delta H^{\circ}=48 \mathrm{kcal} / \mathrm{mol}(\mathrm{P})^{16-18)}
\end{aligned}
$$

where, $\underline{\mathrm{P}}, \underline{\mathrm{O}}$ : the metal components.

From the result obtained, it is found that $\mathrm{Na}_{2} \mathrm{CO}_{3}$ or $\mathrm{Li}_{2} \mathrm{CO}_{3}$ does not serve as an oxidizing agent at least at the last stage of experimental run.

\section{Conclusions}

The dephosphorization of molten pig iron containing $18 \%$ chromium by the addition of $\mathrm{Li}_{2} \mathrm{CO}_{3}$ was studied using a laboratory scale high frequency induction furnace. The results obtained are summarized as follows:

(1) The degrees of dephosphorization, desulfurization and denitrification obtained by adding $60 \sim$ $125 \mathrm{~g} / \mathrm{kg}$-metal of $\mathrm{Li}_{2} \mathrm{CO}_{3}$ to molten pig iron containing chromium in a graphite crucible were more than $80 \%$. On the other hand, the oxidation loss of chromium was less than about $0.5 \%$. Silicon was predominantly oxidized in the range above $0.5 \% \mathrm{Si}$, but silicon and phosphorus were simultaneously oxidized in the range below that.

(2) The degree of dephosphorization by the addition of $\mathrm{Li}_{2} \mathrm{CO}_{3}$ was 2.1 times as large as that by adding $\mathrm{Na}_{2} \mathrm{CO}_{3}$ when the weight of flux added was the same, and 1.5 times when the molar number of flux added was the same. In the case of $\mathrm{Li}_{2} \mathrm{CO}_{3}$ addition the basicity of slag after treatment was high, 
which was considered to be the reason why a large degree of dephosphorization was obtained.

(3) The dephosphorization reaction showed a remarkable temperature dependence. That is, the degree of dephosphorization decreased rapidly with increasing temperature. It was below about $1480{ }^{\circ} \mathrm{C}$ that the temperature giving a large degree of dephosphorization was.

(4) The value of [\% G] had a remarkable effect on $D_{p}$. Vigorous oxidation of chromium was observed in the case of low carbon content. Consequently, the slag lost the fluidity and $D_{p}$ decreased to about $20 \%$ at $[\% \mathrm{C}]=3.5$.

(5) By X-ray diffraction analysis, $\mathrm{Li}_{4} \mathrm{SiO}_{4}$ and $\mathrm{LiCrO}_{2}$ were identified in the slag after treatment, and $\mathrm{Li}_{3} \mathrm{PO}_{4}$ in the phosphorus-enriched slag. From the above facts, it is presumed that chromium oxide behaves as an acidic oxide in the slag and phosphorus is stabilized as lithium phosphate.

\section{REFERENCES}

1) M. Kowaka and H. Fujikawa: J. Japan Inst. Metals, 34 (1970), 1047

2) H. Watanabe and T. Maekita: Tetsu-to-Hagané, 67 (1981), S421.

3) Y. Nakamura and S. Abe: Seitetsu Kenkyu, 289 (1976), 85
4) S. Kawashima, Y. Aoyama, F. Fukui, S. Inoue and K. Harada: Tetsu-to-Hagané, 62 (1976), 1386.

5) K. Osaki and H. Kanezashi: Tetsu-to-Hagané, 66 (1980), S1250.

6) M. Kawakami: Scand. J. Met., 5 (1976), 113.

7) Y. Nakamura: Bull. Japan. Inst. Metals, 15 (1976), 387.

8) Y. Nakamura, N. Tokumitsu, K. Harashima and K. Segawa: Trans. ISIJ, 16 (1976), 623.

9) Y. Nakamura, M. Ito and K. Harashima: Tetsu-to-Hagané, 64 (1978), 402.

10) Y. Nakamura, K. Harashima and M. Ito: Tetsu-to-Hagané, 63 (1977), 2287.

11) K. Kaneko, N. Sano, S. Takeuchi, S. Shiomi and Y. Matsushita: Tetsu-to-Hagané, 63 (1977), 2292.

12) H. Katayama, H. Kajioka, M. Inatomi and K. Harashima: Tetsu-to-Hagané, 65 (1979), 1167.

13) T. Ikeda, M. Taga and T. Matsuo: Tetsu-to-Hagané, 65 (1979), S739.

14) K. Kitamura, T. Takenouchi and K. Suzuki: Tetsu-toHagané, 66 (1980), S227.

15) K. Kitamura, T. Takenouchi and K. Suzuki: Tetsu-toHagané, 66 (1980), S894.

16) I. Barin and O. Knacke: Thermochemical Properties of Inorganic Substances, Springer-Verlag, Berlin, (1973).

17) H. Suito, H. Ishisaka, R. Inoue and Y. Takahashi: Tetsuto-Hagané, 65 (1979), 1848.

18) J. F. Elliott, M. Gleiser and V. Ramakrishna: Thermochemistry for Steelmaking, Addison-Wesley Publishing Co., Mass., (1963), 617. 